\title{
Similar results of valve replacement with normal aortic annulus or anterior and posterior annular enlargement
}

\author{
Resultado da substituição aórtica por ampliação anelar anterior e posterior é comparável a do anel normal
}

João Ricardo M. SANT'ANNA ${ }^{1}$, Felipe W. DE BACCO², Roberto T. SANT'ANNA², Renato A.K. KALIL ${ }^{3}$, Paulo R. PRATES ${ }^{4}$, Ivo A. NESRALLA ${ }^{5}$

RBCCV 44205-708

\begin{abstract}
Objective: To compare results of aortic valve replacement in patients with normal valve annulus and in those requiring annular enlargement.

Method: Study includes 22 patients submitted to anterior and posterior annulus enlargement and 23 patients with a normal aortic annulus. Both groups were matched in gender, age, valvar lesion, etiology of cardiac disease and associated lesions. Patients with normal annuli had usual valve replacement. For those who required annular enlargement, posterior enlargement was performed by incision in the mid portion of the non-coronary sinus up to the anterior mitral leaflet. Anterior enlargement resulted from an incision between left and right coronary ostia extended to the ventricular septum for $2 \mathrm{~cm}$. The aorta was reconstructed using bovine pericardium patches. The diameter of aortic annulus at surgery, clinical evolution ( 2 to 11 years followup) and left outflow tract obstruction (Doppler echocardiography) were considered.
\end{abstract}

Results: Enlargement increased aortic annulus from 18.3

1 - Surgeon of the Cardiovascular Surgery Department of IC/FUC Professor of post graduation program in health sciences of the University Cardiology Foundation (FUC-RS). Researcher in CNPq. 2 - Scientific initiation student IC/FUC-CNPq.

3 - Surgeon of the Cardiovascular Surgery Department of IC/FUC. Assistant Professor Responsible for the Cardiology Department of FFFCMPA. Professor of post graduation program in health sciences of the University Cardiology Foundation (FUC-RS).

4 - Surgeon of the Cardiovascular Surgery Department of IC/FUC. Responsible for the surgical block of IC/FUC.

5 - Head of the Cardiovascular Surgery Department of IC/FUC. Professor of post graduation program in health sciences of the University Cardiology Foundation (FUC-RS).

Work performed in the Heart Institute in Rio Grande do Sul University Cardiology Foundation

Correspondence address: Unidade de Pesquisa do IC/FUC. Dr. João Ricardo M. Sant'Anna. Princesa Isabel, 370. Santana. Porto Alegre, RS, Brasil. CEP 90620-001. Phone/Fax: (51) 3230-3600 r. 3777.

E-mail: pesquisa@cardiologia.org.br $\pm 2.2 \mathrm{~mm}$ to $24.8 \pm 2.0 \mathrm{~mm}(\mathrm{p}<0.001)$, a value similar to those with normal aortic annulus: $24.9 \pm 1.5 \mathrm{~mm}$ (NS). Cardiopulmonary bypass time was longer in patients with enlargement (122.1 $\pm 38.9 \mathrm{~min}$ vs. $91.0 \pm 30.7 \mathrm{~min} ; \mathbf{p}<0.005)$, as was aortic cross-clamp time $(91.6 \pm 20.7 \mathrm{~min}$ vs. $68.0 \pm 23.5$ $\min ; \mathbf{p}<0.001)$. For annular enlargement, peak systolic gradient at the prosthesis decreased from $83.6 \pm 22.3 \mathrm{mmHg}$ (pre-operative) to $26.7 \pm 11.4 \mathrm{mmHg}(\mathbf{p}<0.01)$ in the last evaluation. For normal annulus, reduction from $68.2 \pm 28.7$ mmHg to $32.8 \pm 16.2 \mathrm{mmHg}$ occurred $(p<0.001)$ (final values comparable between groups; NS).

Conclusion: The anterior and posterior aortic annulus enlargement technique allowed an increase in the annular diameter and valvar prosthesis, providing up to 11 years followup, a clinical and echocardiographic result similar to those observed in patients with valve replacement with a normal annulus.

Descriptors: Aortic valve stenosis, surgery. Heart valve diseases, surgery. Heart valve prosthesis.
Article received in September, 2004 Article accepted in November, 2004 


\section{Resumo}

Objetivo: Comparar resultados tardios da substituição valvar no anel aórtico com ou sem ampliação.

Método: Incluídos 22 pacientes aórticos com ampliação anelar anterior e posterior por anel pequeno e $23 \mathrm{com}$ diâmetro anelar normal quando da substituição valvar aórtica. Para grupos, foram comparáveis características como sexo, idade, diagnóstico valvar, etiologia da doença e lesões associadas. Substituição valvar simples foi rotineira. Para ampliação anelar posterior foi feita incisão no ponto médio do seio não coronariano, estendida ao folheto mitral anterior; ampliação anterior resultou de incisão no anel aórtico anterior, estendida por $2 \mathrm{~cm}$ no septo interventricular, não transfixado; reconstrução aórtica foi realizada por enxertos de pericárdio bovino. Resultados considerados para toda amostra foram características operatórias, evolução clínica (seguimento de 2 a 11 anos) e gradiente na via de saída do ventrículo esquerdo (VSVE) ao ecocardiograma Doppler.

Resultados: Ampliação aumentou diâmetro anelar aórtico de $18,3 \pm 2,2 \mathrm{~mm}$ para $24,8 \pm 2,0 \mathrm{~mm}(\mathrm{p}<0,001)$, tornando-o

\section{INTRODUCTION}

Aortic annular enlargement to implant a larger prosthesis is recommended when a reduced diameter of the aortic valve annulus due to a congenital malformation, an anatomic formation or the presence of a stenotic prosthesis is observed. In pediatric patients this may be necessary because an enlargement of the prosthetic diameter will not accompany the growth, which could eventually result in stenosis.

To minimize the possibility of obstruction of the left ventricle outflow tract during aortic valve replacement (or this type of obstruction at a later date), annular enlargement techniques are described, which permit implantation of prostheses larger than the original caliber [1-4]. These techniques have different levels of complexity, allow variable degrees of enlargement and are not totally free of risk. A surgical technique to enlarge the annulus from anterior and posterior positions was described by us [5] and more widespread employment will prove its effectiveness over the long term.

The aim of the current study is to show the results of up to 11 postoperative years of patients submitted to surgery using this technique of anterior and posterior enlargement, to compare these results with those obtained from simple aortic valve replacement and to show addition characteristics of this technique. comparável ao normal: $24,9 \pm 1,5 \mathrm{~mm}$ (NS). Foi necessário maior tempo de circulação extracorpórea para ampliação anelar $(122,1 \pm 38,9$ min vs $91,0 \pm 30,7 \mathrm{~min} ; \mathbf{p}<0,005)$ e de pinçamento aórtico $(91,6 \pm 20,7 \mathrm{~min}$ vs $68,0 \pm 23,5 \mathrm{~min} ; p<0,001)$. Para ampliação anelar, o gradiente sistólico máximo na VSVE reduziu de $83,6 \pm 22,3 \mathrm{mmHg}$ no pré-operatório para $26,7 \pm 11,4$ mmHg $(p<0,01)$, recentemente, e na substituição valvar simples a redução foi de $68,2 \pm 28,7 \mathrm{mmHg}$ para $32,8 \pm 16,2$ mmHg $(\mathrm{P}<0,001)$; valores comparáveis para intervalos correspondentes (NS).

Conclusão: Técnica de ampliação anterior e posterior do anel aórtico possibilitou aumento do diâmetro anelar e do substituto protético implantado, sendo que para até 11 anos de seguimento o resultado clínico e ecocardiográfico foi superponível ao da substituição aórtica em pacientes com anel normal.

Descritores: Estenose da valva aórtica, cirurgia. Doenças das valvas cardíacas, cirurgia. Prótese das valvas cardíacas.

\section{METHOD}

\section{Patients}

In this work 45 patients submitted to the implantation of aortic valve prostheses were evaluated in the Heart Institute of Rio Grande do Sul, University Foundation of Cardiology, from 1993 to 2002. For 22 consecutively operated patients with preoperative diagnosis or intraoperative evidence of a small aortic valve annulus diameter, anterior and posterior enlargement was performed with the aim of implanting a larger valve prosthesis than the native valve size. A group of 23 patients in which simple aortic valve replacements were performed as the annular diameter was considered satisfactory by the surgeon, were selected for a comparison with the routine surgical technique, as they could be matched with the study group in respect to age, gender, etiology, valve lesions, associated lesions, previous events, surgery time (and consequent follow-up time) and functional class.

Significant differences were observed between the groups, with predominance to patients with annular enlargement, the prevalence of prior cardiac surgery $(1.32 \pm$ 1.04 versus $0.43 \pm 0.73$ procedures/patient; $p$-value $<0.01$ ) and the sum of previous surgeries and balloon valvuloplasties $(1.73 \pm 0.99$ versus $0.96 \pm 1.11$ procedures/ patient; $\mathrm{p}<0.01)$. Table 1 shows demographic characteristics of the two groups. 
Table 1. Demographic characteristics of patients

\begin{tabular}{|c|c|c|c|}
\hline Characteristic & $\begin{array}{c}\text { Annular } \\
\text { enlargement }\end{array}$ & $\begin{array}{l}\text { Valve } \\
\text { replacement }\end{array}$ & Significance \\
\hline Patients & 22 & 23 & \\
\hline Mean age (years) & $22.90+11.67$ & $24,1+15.68$ & NS \\
\hline Gender & & & NS \\
\hline Female & $9(40.9 \%)$ & $8(34.8 \%)$ & \\
\hline Male & $13(59.1 \%)$ & $15(65.2 \%)$ & \\
\hline Valvar lesion & & & NS \\
\hline Stenosis & $18(81.8 \%)$ & $15(56.5 \%)$ & \\
\hline Insufficiency & $4(36.4 \%)$ & $5(21.75 \%)$ & \\
\hline Double lesion & - & $5(21.75 \%)$ & \\
\hline Etiology & & & NS \\
\hline congenital & $14(63.6 \%)$ & $13(56.5 \%)$ & \\
\hline rheumatic & $8(36.4 \%)$ & $10(43.5 \%)$ & \\
\hline Associated lesions & & & NS \\
\hline Absent & $16(72.8 \%)$ & $20(87.0 \%)$ & \\
\hline Mitral lesion & $3(13.6 \%)$ & $3(13.0 \%)$ & \\
\hline Bicuspid valve & $2(9.1 \%)$ & - & \\
\hline Aortic aneurism & $1(4.5 \%)$ & - & \\
\hline Prior events & & & NS \\
\hline Absent & $20(90.9 \%)$ & $21(91.4 \%)$ & \\
\hline Endocarditis & $2(9.1 \%)$ & $1(4.3 \%)$ & \\
\hline PCA occlusion * & - & $1(4.3 \%)$ & \\
\hline \multicolumn{4}{|l|}{$\begin{array}{l}\text { Prior procedures } \\
\left(\mathrm{N}^{\circ} \text { patients }\right)\end{array}$} \\
\hline balloon plasty & $0.41+0.80$ & $0,17+0.39$ & NS \\
\hline Heart surgery & $1.32+1.04$ & $0,43+0.73$ & $\mathrm{p}<0.01$ \\
\hline All & $1.73+1.11$ & $0,96+1.02$ & $\mathrm{p}<0.01$ \\
\hline Functional class & & & NS \\
\hline II & $16(72.8 \%)$ & $11(47.8 \%)$ & \\
\hline III & $5(22.7 \%)$ & $8(34.8 \%)$ & \\
\hline IV & $1(4.5 \%)$ & $4(17.8 \%)$ & \\
\hline
\end{tabular}

* By percutaneous technique

\section{Surgical technique and perioperative care}

The patients were submitted to the normal preoperative evaluation. The surgery comprised of well established techniques, such as cardiopulmonary bypass at moderate systemic hypothermia (from 28 to $32{ }^{\circ} \mathrm{C}$ ) and myocardial protection using an infusion of crystalloid hypothermic cardioplegic solution (St. Thomas II solution chilled to 4 ${ }^{\circ} \mathrm{C}$ ). The simple valve replacement was performed using the normal technique.

For patients with small valve annuli, the anterior and posterior aortic enlargement technique [5] was started using an inferior longitudinal aortotomy and extending it to the aortic valve annulus, through the medium portion of Valsalva's sinus, corresponding to the non-coronary leaflet. It continued over the annulus and the anterior mitral leaflet
[1]. Anterior aortic annular enlargement was achieved through an incision in the aortic wall at the aortic commissure between the right and left coronary leaflets. The aortic valve ring was sectioned and the incision extended for $2 \mathrm{~cm}$ in the interventricular septum, with a maximum depth of $0.5 \mathrm{~cm}$ (Figure 1). Reconstruction of the left ventricle was initiated at the anterior aortic incision, by the implantation of a bovine pericardial graft preserved in glutaraldehyde. This graft, in a triangular shape to allow for intended enlargement, was sutured from the lower end of the septal incision, on the edges of the ventricular incision and the aortic wall, finishing along the line of the longitudinal aortotomy.

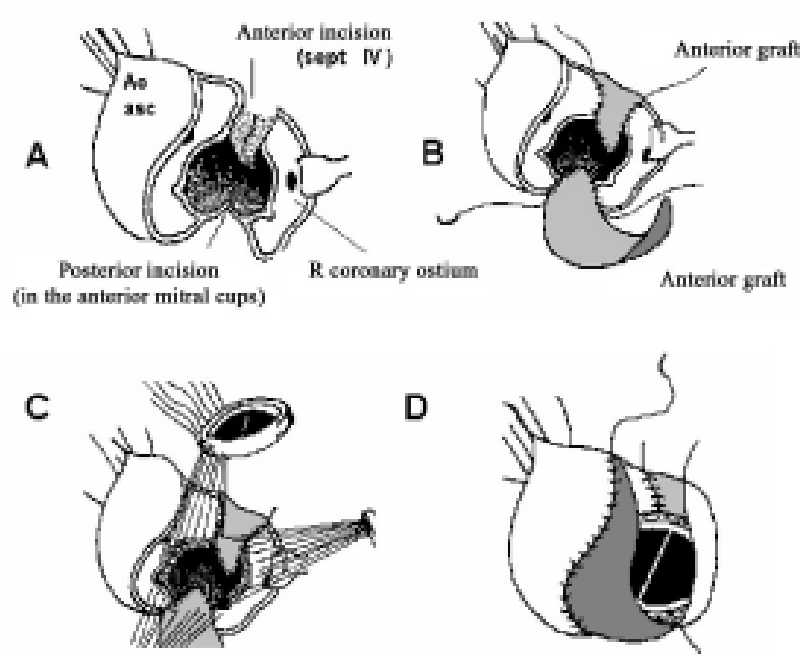

Fig. 1 - Surgery of anterior and posterior amplification (A) Posterior incision (continues to the line of the aortotomy) and anterior (including the interventricular septum) (B) Sutures of the amplification grafts. (C) Anchoring sutures of the aortic prosthesis (D) Reconstruction of the aortic wall with bovine pericardial grafts utilized in the annular amplification.

Abbreviations: asc $\mathrm{Ao}=$ ascending aorta; $\mathrm{IV}$ sept $=$ interventricular septum; $\mathrm{R}=$ right

After this, the reconstruction of the posterior aortic ring was performed using an elliptical-shape bovine pericardial graft preserved in glutaraldehyde with the aim of reconstructing the longitudinal aortotomy to the end of the sutures. The suture started at the mitral valve and extended to the ring and then to the aortic wall, where it was temporally interrupted and tied. After completion of the enlargement, the diameter of the aortic annulus was re-assessed, aiming at verifying the size of the prosthesis to be implanted. The prosthesis was positioned and fixed and the aortorrhaphy concluded by suturing the posterior graft. Figure 1 illustrates the procedure. Other intracardiac procedures were performed, when necessary and the surgery was concluded in the normal manner. 
The patients were kept in the postoperative recuperation room for 48 hours and, after, taken to the postoperative care unit, where they stayed until discharged from hospital. Then, the patients were referred to the assistant physician or to the institution's outpatient clinic.

\section{Surgery evaluation}

Patients were studied in respect to the increase in the diameter of the aortic ring during valve replacement and the resulting anterior and posterior enlargement, late mortality and morbidity, the current quality of life (according to the functional class following the criteria of the New York Heart Association) and the change in the left ventricle outflow gradient (calculated by comparing bidimensional Doppler echocardiograms taken in the preoperative, immediate postoperative and before being discharged from hospital).
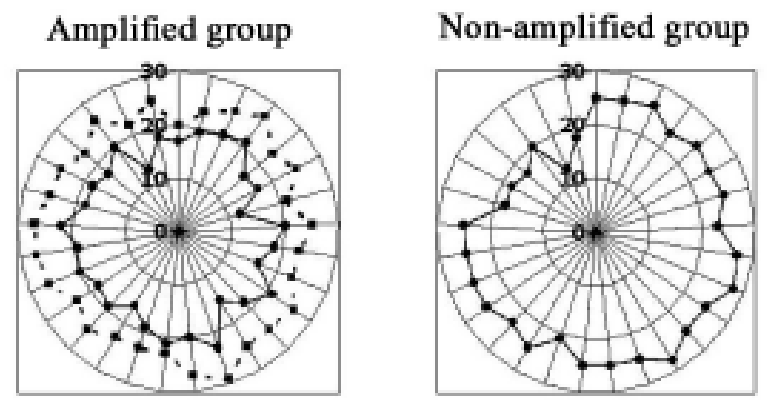

$\rightarrow$ Pre $\cdots$ Post

Fig. 2 - preoperative and pos-operative individual aortic annular diameter in the patients submitted to amplification or simple valve replacement. Numbers refer to the diameter in $\mathrm{mm}$

\section{Ethical considerations and statistic analysis}

For data collection, patient records and the surgery sector computerized files were researched and patients underwent physical examinations. Recent echocardiographic studies were required for all patients. The norms of the research project used in this publication were respected and the study was approved by the Research Ethics Committee of the Heart Institute of Rio Grande do Sul.

The data were written in tables and were compared using Pearson's chi-squared, Fisher's exact and MannWhitney tests. The data were expressed as absolute values, means or percentages and standard errors. The level of stipulated significance was an alpha error of $5 \%$, so p-values of less than 0.05 were reported when identified.

\section{RESULTS}

\section{Intraoperative findings}

Aortic annular posterior and anterior enlargement surgery produced a mean enlargement of the aortic annular diameter of from $18.36 \pm 2.77 \mathrm{~mm}$ to $24.82 \pm 2.01 \mathrm{~mm}(\mathrm{p}<0.001)$. This value was compared to the mean diameter found in patients who underwent simple valve replacement of $24.91 \pm 1.54 \mathrm{~mm}$ (NS). Figure 2 shows individual diameters of aortic annuli of patients from both groups.

The sizes of the implanted prostheses were similar for both groups as seen in Table 2.

For aortic enlargement, a mean cardiopulmonary bypass time of $122.18 \pm 38.93$ minutes was necessary and for simple valve replacement $91.09 \pm 30.76$ minutes were required $(p<0.005)$. The aortic clamping time was $91.64 \pm 20.22$ minutes for patients who underwent enlargement and $68.00 \pm 23.58$ minutes for simple valve replacement $(\mathrm{p}<0.001)$
Table 2. Operative data

\begin{tabular}{llll}
\hline Characteristic & $\begin{array}{l}\text { Annular } \\
\text { enlargement }\end{array}$ & $\begin{array}{l}\text { Valve } \\
\text { replacement }\end{array}$ & Significance \\
\hline $\begin{array}{l}\text { Annular diameter (mm) } \\
\text { Preoperative }\end{array}$ & $18.36+2.77$ & $24.91+1.54$ & $\mathrm{p}<0.001$ \\
$\begin{array}{l}\text { Postoperative } \\
\text { Prosthesis size }\end{array}$ & $24.82+2.06$ & $24.91+1.54$ & $\mathrm{NS}$ \\
19 & 0 & & $\mathrm{NS}$ \\
21 & 8 & 1 & \\
23 & 7 & 4 & \\
25 & 6 & 14 & \\
27 & 1 & 2 & \\
mean & $23.00+1.81$ & $23.00+1.86$ & \\
Operative time & & & $\mathrm{p}<0.005$ \\
& & & \\
CPB time & $122.18+38+93$ & $91.09+30.76$ & \\
Ischemia time & $91.64+20.22$ & $68.00+23.58$ & $\mathrm{p}<0.005$ \\
\hline
\end{tabular}

\section{Late postoperative evaluation}

Current information on all patients of this study was obtained, over follow-up periods of from 2 to 11 years. For patients who underwent anterior and posterior annular enlargement the following late events were identified: postpericardiotomy syndrome which responded well to antiinflammatory medications, aortic bioprosthesis dysfunction requiring a reoperation and atrial fibrillation. In the patients who underwent simple aortic replacement bacterial endocarditis was diagnosed in two patients.

In respect to the clinical condition in the last evaluation, $20(90.9 \%)$ patients submitted to annular enlargement were asymptomatic and showed a physical examination compatible to normal aortic prosthesis function without cardiac insufficiency (functional class I). Two patients (9.1\%) showed symptoms of tiredness and dyspnea with 
effort (functional class II). In relation to the simple valve replacement patients $14(60.9 \%)$ were functional class I, 8 (34.8\%) functional class II and one (4.3\%) functional class III, giving significant statistical differences between the groups ( $\mathrm{p}<0.05)$, as seen in Table 3 .

Table 3. Late postoperative results

\begin{tabular}{lccc}
\hline Characteristic & $\begin{array}{c}\text { Annular } \\
\text { enlargement }\end{array}$ & $\begin{array}{c}\text { Valve } \\
\text { replacement }\end{array}$ & Significance \\
\hline Functional class & & & $\mathrm{p}<0.05$ \\
I & $20(90.9 \%)$ & $14(60.9 \%)$ & \\
II & $2(9.1 \%)$ & $8(31.8 \%)$ & \\
III & - & $1(4.3 \%)$ & \\
& & & $\mathrm{p}<0.001 *$ \\
LV-Ao gradient (mmHg) & & & $\mathrm{NS}$ \\
Pre operative & $83.65+22.37$ & $68.20+28.75$ & $\mathrm{NS}$ \\
Immediate postoperative & $22.86+11.14$ & $27.95+9.98$ & $\mathrm{NS}$ \\
Post-final & $26.78+11.45$ & $32.87+16.23$ & \\
&
\end{tabular}

* Significance in the comparison between the preoperative and postoperative periods

A significant reduction in the maximum instantaneous systolic gradient was observed in patients submitted to annular enlargement and simple valve replacement, both in the evaluation performed immediately after the operation and in the most recent evaluations. With annular enlargement, the mean value was reduced from $83.65 \pm$ $22.37 \mathrm{mmHg}$ to $22.86 \pm 11.14 \mathrm{mmHg}$ in the immediate postoperative period and $26.78 \pm 11.45 \mathrm{mmHg}$ in the most recent evaluation (in respect to the control, $\mathrm{p}<0.001$ in both cases); with simple valve replacement the gradient reduced from $68.20 \pm 28.75 \mathrm{mmHg}$ to $27.90 \pm 9.98 \mathrm{mmHg}$ and $32.87 \pm$ $16.23 \mathrm{mmHg}$, respectively (with $\mathrm{p}<0.001$ in both cases). Although the mean aortic transvalvar gradient observed in the preoperative period was higher in the patients of the annulus enlargement group compared to the valve replacement group $(p<0.005)$, similar values were seen after the surgery (NS) - Table 3 .

Evaluation of the left ventricle outflow tract through echocardiographic studies in the postoperative period did not show obstructive structures related to the subprosthetic (ventricular) sutures of the bovine pericardium grafts utilized in the anterior and posterior enlargement.

\section{COMMENTS}

To treat smaller than normal aortic orifices, the surgeon must use a technique which permits the implantation of a replacement valve which reduces the left ventricle outflow tract obstruction. The initial measure can be the implantation of a small high performance hemodynamic prosthesis, such as those produced by St. Jude and CarboMedics [6,7]. This is acceptable in elderly patients or patients with smaller body surfaces [8], but the resultant residual gradient can cause clinical repercussions, especially in active patients or those with poorly functioning left ventricles [9].

The techniques of aortic orifice enlargement are utilized when a great increase in the aortic annular diameter is necessary; making the implantation of an aortic prosthesis

two or more sizes larger than the native ring possible.

They can be classified according to the anatomic site where the annular sectioning is performed.

Posterior annular enlargement, by sectioning the valve ring and extension of the incision to the mitral valve anterior leaflet has several variations. One technique is composed of a longitudinal aortotomy or sigmoid extended to the lateral wall and the posterior aorta, sectioning the aortic ring in the medium region of the non-coronary artery leaflet $[1,10]$. The aortic incision is extended through the mitral valve ring by up to $1 \mathrm{~cm}$ of its anterior leaflet. A surgical alternative is the extension of the aortotomy to the region of the commissure between the non-coronary artery and the left coronary artery leaflets and the junction of the aortic and mitral rings, without the necessity of incising the mitral leaflet $[2,11]$. In all of these cases, an ample graft is sutured from the inferior portion of the incision, to arrange the enlargement and to reconstruct the aorta. The published results for the posterior enlargement indicate a reduction in the hospital mortality to almost zero $[12,13]$, although there is a possibility of complications related to the mitral valve functioning.

Anterior enlargement of the aortic annulus is performed by aortoventriculoplasty or by the Konno-Rastan surgery $[3,4]$. It is primarily indicated for cases which associate aortic valve stenosis with an obstruction in a subvalvar position, such as in the aorto-ventricular tract, but it can be used for aortic valve stenosis in isolation, especially when a greater annular enlargement is desirable, as in pediatric patients or even in adults. The procedure has high surgical risk (dropping in more recent publications, because it was originally $50 \%$ ) and it is associated with significant complications, such as septal infarction, residual interventricular communications and atrioventricular obstructions $[14,15]$.

In a few procedures, usually involving reoperations, a combination of a posterior enlargement with aortoventriculoplasty were used to obtain an adequate aortic annular diameter [13]. However a combined posterior and anterior enlargement, using a single graft was described by YAMAGUCHI et al. [16]. In this technique, the anterior incision does not exceed the aortic ring. In the anterior and posterior enlargement described by us, techniques such as posterior enlargement of the aortic ring $[1,2]$ and the annular anterior sectioning used in aortoventriculoplasty $[3,4]$ were utilized. The degree of originality of the technique evaluated in this study is connected to the anterior approach, where a 
limited longitudinal incision in the interventricular septum is performed, permitting an additional enlargement.

In our series, the increase in the diameter of the aortic valve annulus resulting from the enlargement surgery created sizes comparable to those observed in patients with diameters considered normal during the operation. The concept of "normality" of the annulus in the current work was formed in the preoperative evaluation (in especial in respect to the echocardiography) and from the subjective impression of the surgeon during the operation. No normal value scale of valve diameters was used in either of the procedures, which would result in a more precise estimation of normality [17]. Independently of this, annular enlargement made implantation of similar sized prostheses compared to patients who were not submitted to annular enlargement possible, and this occurred both in patients with native aortic valves and in those previously submitted to valve replacement but who had small valves.

The operative disadvantage of the enlargement technique results, basically, from its elaboration, as it requires a significant greater cardiopulmonary bypass and myocardial ischemia times. Harmful effects of this extended time, which are in the order of $30 \%$ longer, have been neutralized by membrane oxygenators and improvements in the myocardial protection techniques. Thus, an increase in the time necessary for surgical correction becomes acceptable, in particular when considering that some patients who needed annular enlargement had already been submitted to aortic valve procedures either by catheter or by surgery (a mean of 1.73 interventions per patient), conditions that make the surgery difficult, but do not impede it.

The expectation of favorable late results with larger aortic prosthesis implantation than the original valve annulus was used (allowed by the enlargement) was confirmed when compared with the results obtained from patients submitted to aortic valve replacement without annular enlargement. The prevalence of complications during the follow-up period was low for both groups and similar to published results from different studies on aortic valve replacement $[18,19]$.

The clinical improvement due to aortic valve replacement (and associated cardiac procedures when they were performed) was significant, as in the last evaluation $90.9 \%$ of the patients submitted to annular enlargement were found in functional class I and $9.1 \%$ in class II, results significantly more favorable than observed in simple valve replacement, when $60.9 \%$ of patients were in class I and $34.8 \%$ in functional class II.

In relation to the echocardiographic evaluation, significant differences were not observed between the two groups in respect to the left ventricular outflow tract gradient for corresponding periods of evaluation, but aortic valve replacement resulted in a significant reduction of the obstruction with, in the last evaluation, a left-ventricular- aorta gradient of $26.78 \pm 11.45 \mathrm{mmHg}$ for annular enlargement patients and $32.87 \pm 16.23 \mathrm{mmHg}$ for simple valve replacement patients.

It is important to stress that late results observed in the study must be considered with caution in relation to the number of patients who were considered for the annular enlargement surgical technique and variable follow-up times of from 2 to 11 years. Studies referring to patients with valve diseases include a greater number of patients and those about valvar prostheses consider longer follow-up times than the present study. The number of patients and the follow-up time of between 2 and 11 years are justified by the limited applicability of the technique in question. Considering that the hemodynamical performance (and its clinical repercussions) of the implanted prostheses is well known, we tried to consider in this study findings that could assess the behavior of the proposed technique, so for this reason the results included a comparison of patients with similar characteristics, except in respect to the annular diameter.

\section{CONCLUSION}

Even though the number of evaluated patients was small and the follow-up time was relatively short, this study allows us to conclude that anterior and posterior annular enlargement surgery for aortic valve replacement shows similar results to isolated valve replacement and it can be utilized when the implantation of aortic valve prosthesis larger than the native annulus is necessary.

\section{BIBLIOGRAPHIC REFERENCES}

1. Nicks R, Cartmill T, Bernstein L. Hypoplasia of the aortic root: the problem of aortic valve replacement. Thorax 1970;25:339-46.

2. Manouguian S, Seybold-Epting W. Patch enlargement of the aortic valve ring by extending the aortic incision into the anterior mitral leaflet: new operative technique. J Thorac Cardiovasc Surg 1979;78:402-12.

3. Konno S, Imai Y, Iida Y, Nakajima M, Tatsuno K. A new method for prosthetic valve replacement in congenital aortic stenosis associated with hypoplasia of the aortic valve ring. J Thorac Cardiovasc Surg 1975;70:909-17.

4. Rastan H, Koncz J. Aortoventriculoplasty: a new technique for the treatment of left ventricular outflow tract obstruction. J Thorac Cardiovasc Surg 1976;71:920-7. 
5. Sant'Anna JR, Kalil RAK, Prates PR, Jungblut C, Nesralla IA. Dupla ampliação anterior e posterior do anel aórtico para substituição valvar. Rev Bras Cir Cardiovasc 2002;17:35-46.

6. Foster AH, Tracy CM, Greenberg GJ, McIntosh CL, Clark RE. Valve replacement in narrow aortic roots: serial hemodynamics and long-term clinical outcome. Ann Thorac Surg 1986;42:506-16.

7. De Paulis R, Sommariva L, Russo F, Tomai F, Tondo A, Pagliaricci $\mathrm{C}$ et al. Doppler echocardiography evaluation of the CarboMedics valve in patients with small aortic annulus and valve prosthesis-body surface area mismatch. J Thorac Cardiovasc. Surg 1994;108:57-62.

8. Gehlot A, Mullany CJ, Ilstrup D, Schaff HV, Orszulak TA, Morris JJ et al. Aortic valve replacement in patients aged eighty years and older: early and long-term results. J Thorac Cardiovasc Surg 1996;111:1026-36.

9. Morris JJ, Schaff HV, Mullany CJ, Rastogi A, McGregor CG, Daly RC et al. Determinants of survival and recovery of left ventricular function after aortic valve replacement. Ann Thorac Surg 1993;56:22-30.

10. Blank RH, Pupello DF, Bessone LN, Harrison EE, Sbar S. Method of managing the small aortic annulus during valve replacement. Ann Thorac Surg 1976;22:356-61.

11. Rittenhouse EA, Sauvage LR, Stamm SJ, Mansfield PB, Hall DG, Herndon PS. Radical enlargement of the aortic valve and outflow tract to allow valve replacement. Ann Thorac Surg 1979;27:367-73.
12. Osinowo O, Ross JK, Monro JL. Aortic root enlargement with glycerol preserved homologous dura mater patch during aortic valve replacement. Thorac Cardiovasc Surg 1985;33:23-5.

13. Meyer M, Lucchese FA, Coutinho JH. Tratamento do anel aórtico pequeno: manuseio da desproporção anel aórtico/ prótese. In: 20o Congresso Nacional de Cirurgia Cardíaca. Maceió: Sociedade Brasileira de Cirurgia Cardiovascular; 1993.

14. Flemming WH, Sarafian LB. Aortic valve replacement with concomitant aortoventriculoplasty in children and young adults: long-term follow-up. Ann Thorac Surg 1987;43:575-8.

15. Frommelt PC, Lupinetti FM, Bove EL. Aortoventriculoplasty in infants and children. Circulation 1992;86(5 suppl.):II-176-80.

16. Yamaguchi M, Ohashi H, Imai M, Oshima Y, Hosokawa Y. Bilateral enlargement of the aortic ring for valve replacement in children: new operative technique. J Thorac Cardiovasc Surg 1991;102:202-6.

17. Rowlatt JE, Rimoldi JHA, Lev M. The quantitative anatomy of the normal child's heart. Pediat Clin North Am 1963;10:499-589.

18. Bloonfield P, Wheatley DJ, Prescott RJ, Miller HC. Twelveyear comparison of a Björk-Shiley mechanical heart valve with porcine bioprostheses. N Eng J Med 1991;324:573-9.

19. Hammermeister KE, Sethi GK, Henderson WG, Oprian C, Kim T, Rahimtoola S. A comparison of outcomes in men 11 years after heart-valve replacement with a mechanical valve or bioprosthesis. Veterans Affairs Cooperative Study on Valvular Heart Disease.N Eng J Med 1993;328:1289-96. 